\title{
Mathematical and Computer Simulation of the Biological Life Support System Module 1/2. Description of the Model
}

\author{
Vladimir G. Gubanov $^{a}$, Yury V. Barkhatov ${ }^{a *}$, \\ Nikolai S. Manukovskya, Alexander A. Tikhomirov ${ }^{\mathrm{a}, \mathrm{b}}$, \\ Andrey G. Degermendzhy ${ }^{\mathrm{a}, \mathrm{b}}$, Jean-Bernard B. Gross ${ }^{\mathrm{c}}$, \\ Christophe Lasseur ${ }^{d}$ \\ ${ }^{a}$ Institute of Biophysics of Siberian Branch of Russian Academy of Sciences, \\ Akademgorodok, Krasnoyarsk, 660036 Russia \\ ${ }^{b}$ Siberian Federal University, \\ 79 Svobodny, Krasnoyarsk, 660041 Russia \\ ${ }^{c}$ LGCB, Universiter B.Pascal, \\ CUST, BP206, 63174 Aubie're cedex France \\ ${ }^{d}$ Environmental Control and Life Support section, \\ ESA-Estec, Postbus 299, 2200 AG, Noordwijk, Netherlands ${ }^{I}$
}

Received 7.12.2009, received in revised form 14.12.2009, accepted 21.12.2009

The mathematical model based on kinetic coefficients and dependencies obtained during the experiments was constructed to estimate the character of functioning of the experimental module of biological life support system (BLSS) and the possibilities of its controlling. The mathematical model consists of two compartments - the 'phytotron' model (with wheat and radish) and the 'mycotron' model (for mushrooms). The following components are included into the model: edible mushrooms (mushroom fruit bodies and mycelium); wheat; radish; straw (processed by mycelium); dead organic matter in the phytotron (separately for the wheat unit and for the radish unit); worms; worms' coprolites; vermicompost used as a soil-like substrate (SLS); bacterial microflora; mineral nitrogen, phosphorus and iron; products of the system intended for humans (wheat grains, radish roots and mushroom fruit bodies); oxygen and carbon dioxide. At continuous gas exchange, the mass exchange between the compartments occurs at the harvesting time. The conveyor character of the closed ecosystem functioning has been taken into account - the number of culture age groups can be controlled (in experiments and in the model - 4 and 8 age groups). The conveyor cycle duration can be regulated as well. The module was designed for the food and gas exchange requirements of 1130 of a virtually present human. The model estimates the values of all dynamic components of the system under various conditions and modes of functioning, especially those, which are difficult to be realized in the experiment. The model allows dynamic calculation of biotic turnover closedness coefficient for main considered elements. The coefficient of matter biotic cycle closure for systems based on matter supplies has been formalized.

Keywords: Mathematical modeling, biological life support system, closedness coefficient

\footnotetext{
Corresponding author E-mail address: barkh@ibp.ru
}

(C) Siberian Federal University. All rights reserved 


\section{Introduction}

The mathematical model based upon kinetic coefficients and dependencies obtained during the experiments was constructed to estimate the functioning pattern of the biological life support system (BLSS) experimental module (Tikhomirov et al., 2003a, 2003b) and its controllability. The mathematical model consists of three compartments - two 'phytotron' models (with wheat and radish) and the 'mycotron' model (for mushrooms). The following components are included into the model: edible mushrooms (mushroom fruit bodies and mycelium); wheat; radish; straw (processed by mycelium); dead organic matter in the phytotron (separately for the wheat unit and for the radish unit); worms; worms' coprolites; vermicompost used as a soil-like substrate (SLS); bacterial microflora; mineral nitrogen, phosphorus and iron; products of the system intended for humans (wheat grains, radish roots and mushroom fruit bodies); oxygen and carbon dioxide. At continuous gas exchange, the mass exchange between the compartments occurs at the harvesting time. The conveyor character of the closed ecosystem functioning has been taken into account - the number of culture age groups can be controlled (in experiments and in the model -4 and 8 age groups). The conveyor cycle duration can be regulated as well. The module was designed for the food and gas exchange requirements of $1 \backslash 30$ of a virtually present human.

The model also allows for the following processes: photosynthesis of wheat and radish in relation to the crop age, irradiance, the amount of biogenic elements; respiration of mushrooms, worms, bacteria and a human; consumption of grain and radish roots by a human and a return of biogenic elements in the mineral form; utilization of dead phytomass by worms and bacteria; processing of wheatstraw by mushroom mycelium; conversion of worms' coprolites into the mineral form by bacteria. Continuous dynamic processes going in each of three system compartments are described by differential equations written in terms of mass using subsidiary conditions for parameters and discrete relations.

The model estimates the values of all dynamic components of the system under various conditions and modes of functioning, especially those, which are difficult to be realized in the experiment. Themodelallowsdynamic calculation of biotic turnover closedness coefficient for main considered elements. The ratio of any $\mathrm{i}^{\text {th }}$ biogenic element flow on the producer link to the sum of the same flow and the flow of element coming into the deadlock sediments is the closure measure of any $\mathrm{i}^{\text {th }}$ element (coefficient $\mathrm{Cli}$ ).

\section{BLSS experimental module}

We present brief description of the BLSS module and methods of working with it (more detailed description can be found elsewhere (Tikhomirov et al., 2003a, 2003b)). The experimental model of a BLSS consists of three interrelated components: autotrophic, heterotrophic, and physicochemical. The autotrophic component is represented by two plant species: the short-stemmed Triticum aestuvi L. spring wheat (cultivar 232, selected by G.M. Lisovsky) and Raphanus sativus L. the radish cultivar Virovskii White. These plant species have been extensively used in life support systems (Gitelson et al., 1975; Zamknutaya sistema... (Closed system...), 1979). In this BLSS model the plants were grown under continuous lighting at 150-170 $\mathrm{W} / \mathrm{m}^{2}$ of photosynthetically active radiation (PAR). The plants were grown in rectangular chambers $0.155 \mathrm{~m}$ high, with the bottom area $0.032 \mathrm{~m}^{2}(0.22 \times 0.145)$. Wheat was grown in 16 chambers, radish in 8 . During the growth period, the chambers were placed very close to each other, so that wheat and radish formed their 
cenoses. The growth period of the wheat was 64 days. The growth period of the radish was 32 days. To decrease the age dependence of plant photosynthesis, an uneven-aged conveyor was organized in the system (Gitelson, Lisovsky, Tikhomirov, 1997). In the conveyor, wheat was represented by 8 age groups and radish by 4 .

The main representatives of the heterotrophic unit were mushrooms, worms, and bacterial microflora. The mushroom component was represented by the oyster mushroom Pleurotus ostreatus (Jacq.: Fr.) Kummer, a higher edible mushroom. The mushrooms $P$. ostreatus were grown in non-sterile conditions, on straw wheat, during 60-70 days; carposomes formed within two, sometimes three, generations and constituted 6-7 g per $100 \mathrm{~g}$ of the substrate (dry basis). When the growth was completed, the unutilized portion of lignocelluloses - the residual substrate - amounted to $40-45 \%$ of the initial mass. The residual substrate was used to prepare vermicompost or as an organic fertilizer for the plants.

The worm component was represented by the red California worm, a hybrid close to Eisenia foetida Savigny. The worms facilitated the utilization of the abovementioned residual substrate, radish tops, and other organic substrates. During 60 days, five worms normally introduced into $100 \mathrm{~g}$ of moist substrate formed 25-30 g of vermicompost organic substance used as soil-like substrate (SLS) to grow wheat and radish plants in the system. SLS is a product of continuous conversion of gramineous culture straw (wheat, rice etc.) by wood-destroying fungus P. ostreatus and worms E. foetida. In its main characteristics SLS is similar to organic soils (histosols), but it differs from them by the absence of aluminosilicate matrix. Prior to the launch of the system, the starting SLS was made from wheat straw, using mushrooms and worms, following the procedure described elsewhere (Manukovsky et al., 1996, 1997).

Structurally, the BLSS model consisted of two hermetically sealed chambers, $3 \mathrm{~m}^{3}$ in volume each (Fig. 1). The gas exchange between the chambers was continuous, through air pipes. The air exchange between the chambers was effected with a fan. In the chamber used for cultivation of wheat and radish on the SLS the air temperature was maintained at $24 \pm 1^{\circ} \mathrm{C}$. In the other chamber, where mushrooms matured and bore fruit, the temperature was maintained at $19^{\circ} \mathrm{C}$, the humidity at $90 \%$, and the irradiation at $15 \mathrm{~W} / \mathrm{m}^{2}$ PAR. The $\mathrm{CO}_{2}$ concentration in the entire system was maintained at $0.11 \pm 0.03 \%$ and the oxygen concentration at $20,6-21,5 \%$. Higher plant photosynthesis produced surplus oxygen, necessary for human respiration, i.e. $\mathrm{O}_{2} / \mathrm{CO}_{2}>1$ (the last ratio refers to $\mathrm{O}_{2}$ and $\mathrm{CO}_{2}$ consumptionproduction not to their concentrations). Every day, a human periodically breathed through a special mask to equalize this ratio and maintain it balanced. The system was designed for the food and gas exchange requirements of $1 / 30$ of a virtually present human.

At the start, the experimental system was supplied with $120 \mathrm{~L}$ of distilled water, including $70 \mathrm{~L}$ of irrigation water and $50 \mathrm{~L}$ of the water as part of the SLS, plants, and other organic matter.

To collect and analyze the experimental data, the system was opened once in eight days for four hours. That time was spent on removing chambers with mature plants out of the chamber and on collecting samples of the phytomass: wheat grains, straw, and roots; radish tops and both edible and inedible roots. After these components of the phytomass were removed from the growth chambers, worms were counted in the remaining SLS, the SLS mass was determined, and samples were taken for analysis. The organic matter left after sampling was returned to the respective growth chambers, which were placed back 


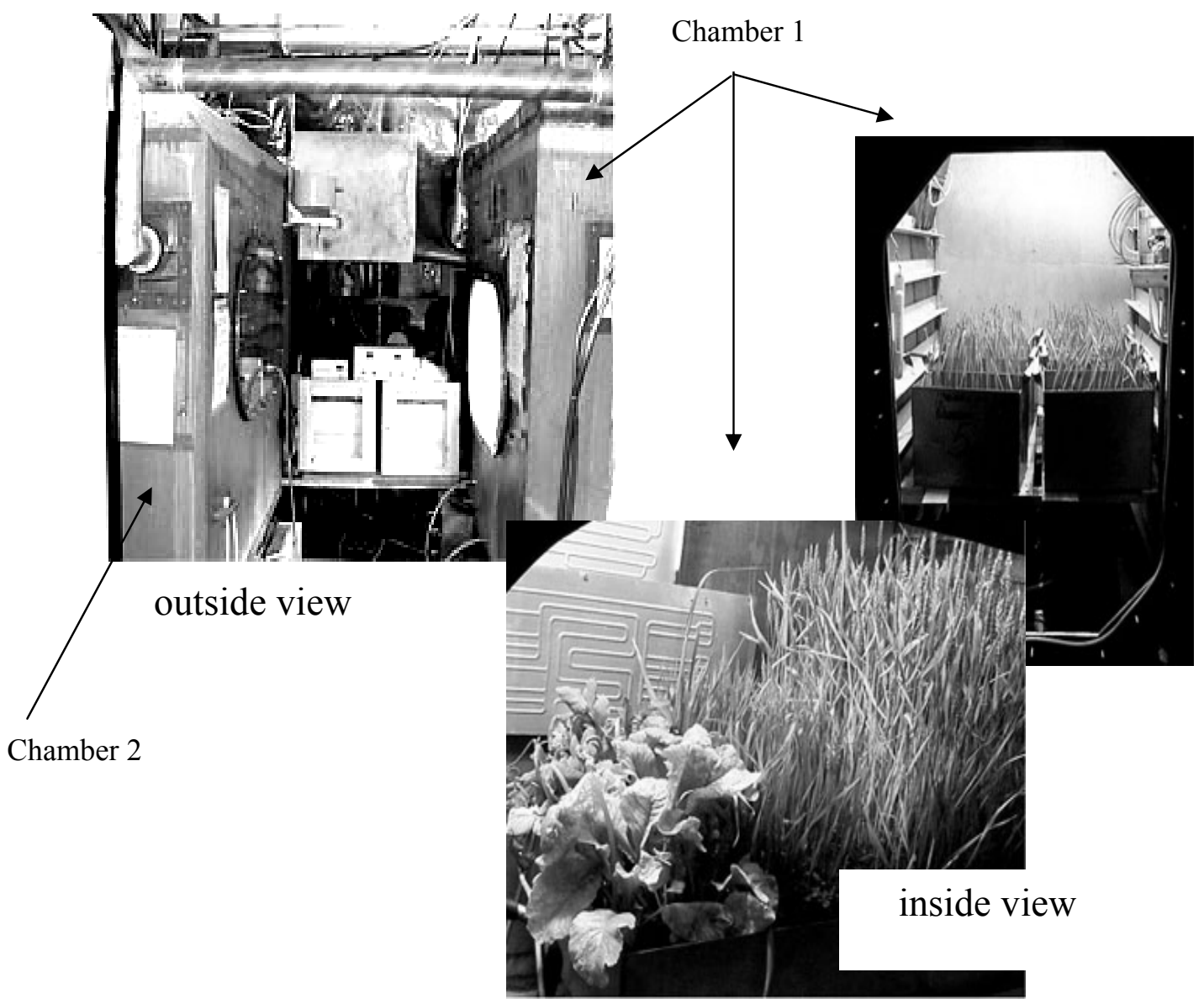

Fig. 1. A small experimental life support system (with a $1 / 30$ fraction of virtually present human) with increased closure degree. Chamber 1 - phytotron - autotrophic unit; chamber 2 - mycotron - heterotrophic unit

into the plant growth chamber. The harvested wheat straw was used to make the substrate for mushrooms. The $P$. florida mycelium was grown in stainless-steel cylindrical containers in the plant growth chamber at a temperature of $25^{\circ} \mathrm{C}$ during 3 weeks. Then the containers were placed into the other chamber, where the mushrooms matured and fruited.

Edible biomass - grains, roots, mushrooms were oxidized in the physicochemical reactor, to simulate their consumption by a human. The oxidation products - inorganic compounds readily assimilated by plants - were returned into the system. The physicochemical method of waste utilization is based on using hydrogen peroxide, which can be derived from water within the system. Unlike other physicochemical methods based on this principle, this one does not require high temperatures or pressures and is energy efficient, environmentally friendly, and safe (Kudenko et al, 1997). To maintain the physicochemical process, no auxiliary chemical substances or other ingredients, which have to be taken as a store, are needed.

The output oxidation products were metabolite water, carbon dioxide, and mineral residue. The mineral residue consisted of the mineralized organic matter $\left(\mathrm{NH}_{4}{ }^{+}, \mathrm{SO}_{4}{ }^{2-}\right)$ and phytomass ash ( $\mathrm{P}, \mathrm{K}, \mathrm{Mg}, \mathrm{Ca}, \mathrm{Na}, \mathrm{S}, \mathrm{Si})$. The mineral residue was returned to the irrigation water. Thus, oxidation yielded a solution of oxides that did not contain any substances harmful for plants. It was added to the SLS as a nutrient for plants. 


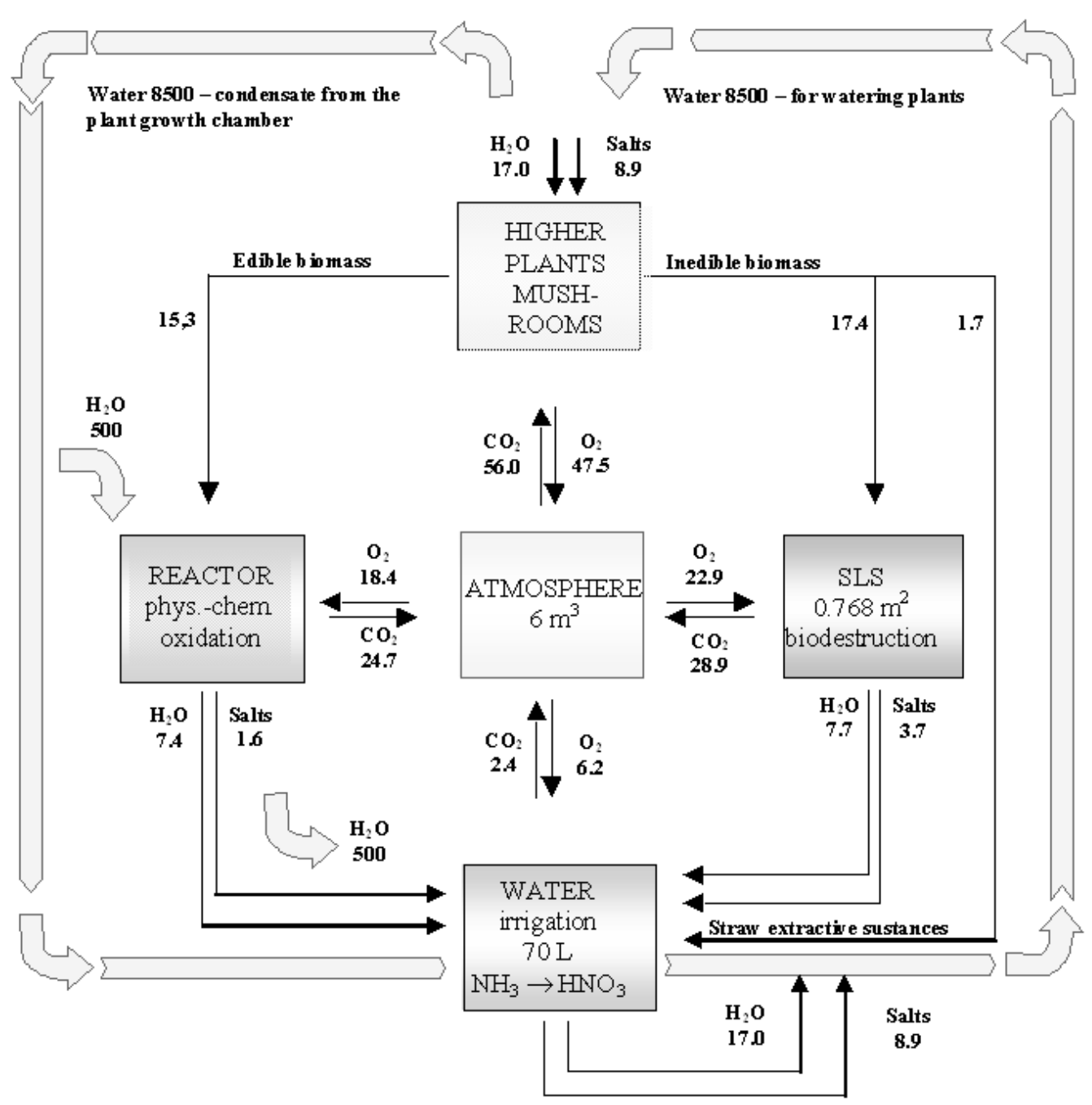

Fig. 2. Scheme of mass exchange in the experimental system системе (Tikhomirov et al., 2003a, 2003b). Material flows are given as g/day. Broad arrows show the water exchange circuit. Flows of metabolite water are given separately. The SLS mass in the system was $15 \mathrm{~kg}$ (dry basis)

After the oxidation of the edible biomass in the reactor, the carbon dioxide was returned into the system. The destruction rates of the substance were calculated based on the chemical composition of the phytomass. The experiment with the system, which was in a quasi-stationary state, lasted about 90 days. The general scheme of the material balance and water exchange in the experimental system can be seen in Fig. 2. This scheme displays the material balance in the experimental system where the processes of photosynthesis of wheat and radish biomass are counterbalanced by the processes of biodestruction of inedible phytomass in the SLS and by oxidation of grains, edible roots, and mushroom carposomes in the physicochemical reactor.

In the scheme the photosynthesis of the plant biomass and the biosynthesis of mushrooms from the wheat straw are shown as parts of one unit. In this unit, the processes of synthesis are counterbalanced by the processes of oxidation of edible biomass (grains, edible roots, and mushrooms) in the physicochemical reactor and by the processes of biodestruction of inedible phytomass (tops, roots, residual substrate) in the 
SLS and of extractive substances in the irrigation water.

\section{Mathematical model of the BLSS module}

The mathematical model (primary description of which is given in (Gubanov et al., 2007) based on kinetic coefficients and dependencies obtained during the experiments was constructed to estimate the character of functioning of the experimental module BLSS and the possibilities of its controlling.

The mathematical model consists of two compartments - the 'phytotron' model (with wheat and radish) and the 'mycotron' model (for mushrooms). The following components are included into the model: edible mushrooms (mushroom fruit bodies and mycelium); wheat; radish; straw (processed by mycelium); dead organic matter in the phytotron (separately for the wheat unit and for the radish unit); worms; worms' coprolites; vermicompost used as a soil-like substrate (SLS); bacterial microflora; mineral nitrogen, phosphorus and iron; products of the system intended for humans (wheat grains, radish roots and mushroom fruit bodies); oxygen and carbon dioxide. Flow chart of the model is presented in Fig. 3.

At continuous gas exchange, the mass exchange between the compartments occurs at the harvesting time. The conveyor character of the closed ecosystem functioning has been taken into account - the number of culture age groups can be controlled (in experiments and in the model 4 and 8 age groups). The conveyor cycle duration can be regulated as well. The module was designed for the food and gas exchange requirements of $1 \backslash 30$ of a virtually present human.

The model also allows for the following processes: photosynthesis of wheat and radish in relation to the crop age, irradiance, the amount of biogenic elements; respiration of mushrooms, worms, bacteria and a human; consumption of grain and radish roots by a human and a return of biogenic elements in the mineral form; utilization of dead phytomass by worms and bacteria; processing of wheat straw by mushroom mycelium; conversion of worms` coprolites into the mineral form by bacteria.

\subsection{Description of continuous \\ dynamic processes}

Let us examine the structure of the model in greater detail. First, the continuous dynamic processes going in each of three system compartments, described by differential equations written in terms of mass, should be conceived.

\subsection{1. 'Mycotron' model}

The growth rate of mushroom mycelium $F_{m}$ is defined as:

$$
\frac{d F_{m}}{d t}= \begin{cases}\left(\mu_{m}-\gamma_{m}\right) F_{m} & , \dot{F}_{m} \geq 0 \\ \left(\mu_{m}-\gamma_{m}\right) F_{m}-f F & , \dot{F}_{m}<0\end{cases}
$$

where $\mu_{m}$ is mycelium specific growth rate, $\gamma_{m}$ is the specific rate of mycelium metabolism, $f$ is the specific rate of fruit bodies growth (formation), $F$ is the mass of mushroom fruit bodies.

$$
\begin{aligned}
& \mu_{m}=L_{O_{2}} \frac{\hat{\mu}_{m} H}{H+K_{H}}, \\
& \gamma_{m}=\gamma^{*}{ }_{m} F_{m}{ }^{k}, \quad 0 \leq k \leq 1,
\end{aligned}
$$

where $L_{\mathrm{O}_{2}}$ is the coefficient of heterotroph growth limitation by the oxygen content in the atmosphere, $\hat{\mu}_{m}$ is the maximum specific growth rate of mycelium, $H$ is the straw biomass in mycotron, $K_{H}$ is the constant of mycelium halfsaturation on straw, $\gamma_{m}{ }_{m}=$ const, $k$ - exponent, any rational number from 0 to 1 .

$L_{\mathrm{O}_{2}}$ is defined as:

$$
L_{\mathrm{O}_{2}}=\left\{\begin{array}{ll}
1 & , Q>Q_{o p t} \\
K_{Q} Q & , Q \leq Q_{o p t}
\end{array},\right.
$$


Growth period $\longrightarrow$

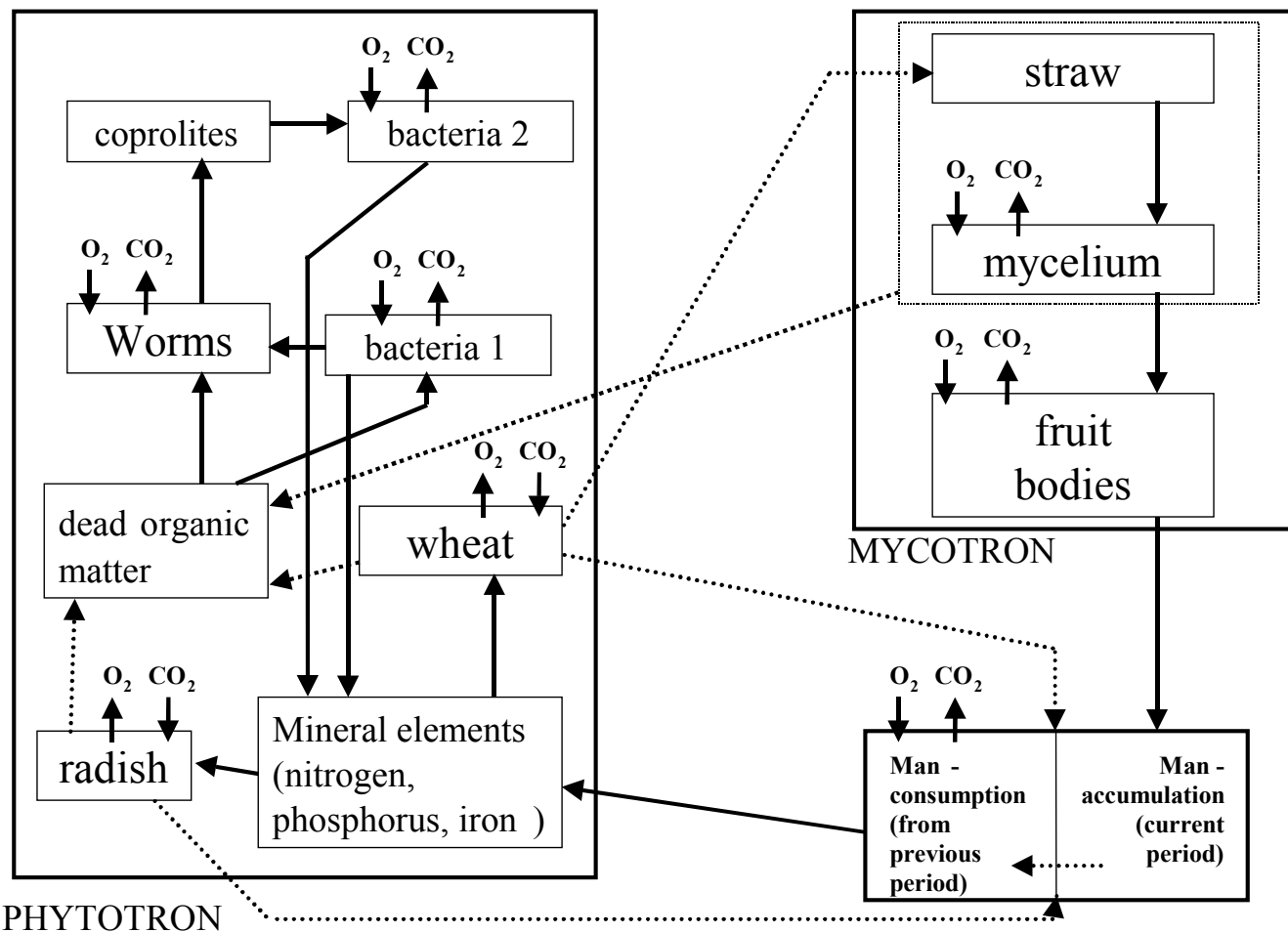

Fig. 3. Flow chart of the mathematical model of the «phytocenosis - soil-like substrate - gas exchange with a human» system. Here, bacteria-1 are responsible for consumption of dead organic matter, bacteria-2 are responsible for consumption of worms' coprolites

where $Q$ is the mass of molecular oxygen in system atmosphere, $Q_{o p t}$ is the content of oxygen in system atmosphere optimal for heterotrophs, $K_{Q}$ is the constant of heterotroph growth limitng by the oxygen content in atmosphere.

The growth rate of mushroom fruit bodies $F$ is written in the form:

$$
\frac{d F}{d t}=\left\{\begin{array}{l}
f F, \frac{d F_{m}}{d t} \geq 0 \\
0, \dot{F}_{m}<0
\end{array},\right.
$$

with subsidiary condition describing the harvesting of mushroom fruit bodies:

$$
F=0 \supset \frac{F}{F_{m}} \leq \varphi,
$$

where $\varphi$ is the maximum possible proportion of mushroom fruit bodies and mycelium mass, $0 \leq \varphi \leq 1, \varphi=$ const; the condition means that harvesting of mushroom fruit bodies takes place when the ratio of fruit bodies' mass and mushroom mycelium amounts to its maximal possible value $\varphi$ and at this moment the value $F$ is «zeroing»fruit bodies are gathered in the harvest.

The rate of straw mass reduction in mycotron $H$ can be written as:

$$
\frac{d H}{d t}=-\frac{\mu_{m} F_{m}}{Y_{H}},
$$

where $Y_{H}$ is the coefficient of mycelium yield on straw.

The rate of «dead end» (the organic matter, which does not take part in matter cycling) formation for mycotron $\left(B_{F}\right)$ is defined as:

$$
\frac{d B_{F}}{d t}=\left(\frac{1}{Y_{H}}-1\right) \mu_{m} F_{m}
$$

\subsection{2. 'Wheat phytotron' model}

The growth rate of the total wheat mass $X_{I}$ is defined as: 


$$
\frac{d X_{1}}{d t}=\mu_{X 1} J_{1}
$$

where $\mu_{X I}$ is wheat specific growth rate, $J_{1}$ is the surface area of wheat growth chamber, at that that,

$$
\mu_{X 1}=k_{1} L_{C O_{2}} L_{E X 1} L_{S 1} c_{1}\left(a_{1}\left(t_{1}-t_{11}\right)-b_{1}\left(t_{1}-t_{11}\right)^{3 / 2}\right),
$$

where $k_{1}$ is the coefficient of photosynthesis dependence of wheat growth rate, $L_{\mathrm{O}_{2}}$ is the coefficient of phototroph growth limitation by carbon dioxide content in system atmosphere, $L_{E X I}$ is the coefficient of wheat growth limitation by illumination, $a_{1}, b_{1}, c_{1}$ are experimental constants, $L_{S l}$ is the coefficient of wheat growth limitation by biogenic elements, $t_{t}$ is the current time for wheat phytotron, $t_{11}$ is the time of wheat grains germination. With respect to dependency (8) see the work (Gitelson et al., 1975).

$$
L_{\mathrm{CO}_{2}}=\left\{\begin{array}{ll}
1 & , W \geq W_{o p t} \\
K_{W} W & , W<W_{o p t}
\end{array},\right.
$$

where $W$ is carbon dioxide mass in the system, $W_{\text {opt }}$ is carbon dioxide content in the system optimal for wheat, $K_{W}$ is the constant of phototrophs limitation by carbon dioxide content in the system.

$$
L_{E_{X 1}}=\left\{\begin{array}{lc}
-0.0076 \cdot E+2.5238, & E \geq E_{\text {opt }} \\
0.0059 \cdot E-0.1707, & E<E_{\text {opt }}
\end{array},\right.
$$

where $E$ is the intensity of system illumination, $E_{o p t}$ is the illumination intensity optimal for wheat. The dependence (10) was obtained by approximation of experimental data (Tikhomirov et al., 2003a).

$$
L_{S 1}=\min \left\{K_{S_{1} 1} S_{1}, K_{S_{2} 1} S_{2}, K_{S_{3} 1} S_{3}, 1\right\},
$$

where $K_{S_{1} 1}, K_{S_{2} 1}, K_{S_{3} 1}$ are the constants of wheat growth limitation by the content of mineral nitrogen, phosphorus and iron respectively in the growth chamber, $S_{1}, S_{2}, S_{3}$ is the content of mineral nitrogen, phosphorus and iron in the growth chamber.
The rate of worms' mass change $G_{l}$ in wheat phytotron is defined as:

$$
\frac{d G_{1}}{d t}=\mu_{G 1} G_{1}-\gamma_{G} G_{1},
$$

where $\mu_{G l}$ is worms' specific growth rate in wheat growth chamber, $\gamma_{G}$ is the specific rate of worms metabolism, where

$$
\mu_{G 1}=L_{O_{2}}\left(\mu_{G R 11}+\mu_{G Z 1}\right),
$$

where $\mu_{\text {GRII }}$ is the specific growth rate of worms on bacteria-1 (bacteria responsible for consumption of dead organic matter) in wheat growth chamber, $\mu_{G Z I}$ is the specific growth rate of worms on dead organic matter in wheat growth chamber.

$$
\begin{aligned}
& \mu_{G Z 1}=\alpha_{Z 1} \hat{\mu}_{G} \frac{Z_{1}}{Z_{1}+K_{G Z}}, \\
& \mu_{G R 11}=\alpha_{R 11} \hat{\mu}_{G} \frac{R_{11}}{R_{11}+K_{R 1}},
\end{aligned}
$$

$Z_{l}$ is the dead organic matter in wheat phytotron, $R_{1} R_{11}$ is the mass of bacteria-1 in wheat phytotron, $\hat{\mu}_{G}$ is the maximum possible specific growth rate of worms, $K_{G Z}, K_{R I}$ are the constants of worms' half-saturation on $Z_{l}$ and $R_{l 1}$ respectively.

Normalizing quotients $\alpha_{Z 1}$ and $\alpha_{R I I}$ are defined (Abrosov et al., 1992; Gubanov, Degermendzhy, 2002) as:

$$
\begin{aligned}
& \alpha_{Z 1}=\frac{1}{A_{G 1}} \cdot \frac{Z_{1}}{Z_{1}+K_{G Z}}, \\
& \alpha_{R 11}=\frac{1}{A_{G 1}} \cdot \frac{R_{11}}{R_{11}+K_{R 1}}, \\
& A_{G 1}=\frac{Z_{1}}{Z_{1}+K_{G Z}}+\frac{R_{11}}{R_{11}+K_{R 1}} .
\end{aligned}
$$

The rate of bacteria-1 mass change in wheat phytotron $R_{1 l}$ is written in the form:

$$
\frac{d R_{11}}{d t}=\mu_{R 11} R_{11}-\gamma_{R 1} R_{11}-\frac{1}{Y_{G R 1}} \mu_{G R 11} G_{1},
$$

where $\mu_{R 11}$ is bacteria-1 specific growth rate in wheat growth chamber, $\gamma_{R I}$ is the specific rate of bacteria-1 metabolism, $Y_{G R I}$ is the coefficient of worms yield on bacteria-1.

$$
\mu_{R 1}=L_{O_{2}} \hat{\mu}_{R 1} \frac{Z_{1}}{Z_{1}+K_{R 1 Z}},
$$


where $\hat{\mu}_{R 1}$ is the maximum specific growth rate of bacteria-1, $K_{R I Z}$ is the constant of bacteria-1 halfsaturation on dead organic matter.

The rate of dead organic matter utilization in wheat phytotron $Z_{1}$ is defined as:

$$
\frac{d Z_{1}}{d t}=-\frac{1}{Y_{R I Z}} \mu_{R 11} R_{11}-\frac{1}{Y_{G Z}} \mu_{G Z 1} G_{1},
$$

where $Y_{R I Z}$ is the coefficient of bacteria-1 yield on dead organic matter, $Y_{G Z}$ is the coefficient of mushrooms yield on dead organic matter.

The change of bacteria-2 (responsible for consumption of worms' coprolites) mass $R_{21}$ is defined as:

$$
\frac{d R_{21}}{d t}=\mu_{R 21} R_{21}-\gamma_{R 2} R_{21},
$$

where $\mu_{R 21}$ is bacteria-2 specific growth rate in wheat growth chamber, $\gamma_{R 2}$ is the specific rate of bacteria-2 metabolism.

$$
\mu_{R 21}=L_{O_{2}} \hat{\mu}_{R 2} \frac{C_{1}}{C_{1}+K_{R 2 C}}
$$

where $\hat{\mu}_{R 2}$ is the maximum specific growth rate of bacteria-2, $C_{l}$ is the mass of worms' coprolites, $K_{R 2 C}$ is the constant of bacteria-2 half-saturation on coprolites.

The change of mass of worms' coprolites $C_{l}$ is written in the form:

$$
\begin{aligned}
& \frac{d C_{1}}{d t}=-\frac{\mu_{R 21} R_{21}}{Y_{R 2 C}}+\left(\frac{1}{Y_{G R 1}}-1\right) \mu_{G R 11} G_{1} \delta_{G R 1}+ \\
& +\left(\frac{1}{Y_{G Z}}-1\right) \mu_{G Z 1} G_{1} \delta_{G Z},
\end{aligned}
$$

where $Y_{R 2 C}$ is the coefficient of bacteria-2 productivity on coprolites, $\delta_{G R l}, \delta_{G Z}$ is the part of worms' excrements used for formation of coprolites, at their consumption of bacteria-1 or dead organics.

The change of mineral nitrogen mass in wheat phytotron $S_{l I}$ can be written as:

$$
\begin{aligned}
& \frac{d S_{11}}{d t}=-\frac{1}{Y_{X 1 S 1}} \dot{X}_{1}+\alpha_{R 2 S 1}^{*}\left(\frac{1}{Y_{R 2 C}}-1\right) \mu_{R 21} R_{21}+ \\
& +\alpha_{R 1 S 1}^{*}\left(\frac{1}{Y_{R 1 Z}}-1\right) \mu_{R 11} R_{11}+\alpha_{U 2 S 1}^{*} \frac{U_{21}\left(t_{i 1}\right)}{t_{\max 1}},
\end{aligned}
$$

where $Y_{X I S I}$ is the coefficient of wheat yield on mineral nitrogen, $\alpha_{R I S I}^{*}, \alpha_{R 2 S I}^{*}, \alpha_{U 2 S I}^{*}$ are the specific content of mineral nitrogen in bacteria-1, bacteria-2 and human metabolites respectively, $U_{2 l}\left(t_{i}\right)$ is the biomass of products intended for a human at the beginning of wheat growth period, $t_{\operatorname{maxl}}$ is the time (duration) of wheat growth period.

The mass change of mineral phosphorus $S_{21}$ and iron $S_{31}$ in wheat phytotron is written in a way similar to nitrogen.

The rate of accumulation of product supplies for humans in the current growth period in mycotron and wheat phytotron $U_{l l}$ is defined as:

$$
\frac{d U_{11}}{d t}=0
$$

with a subsidiary condition describing the harvesting of mushroom fruit bodies:

$$
U_{11}=U_{11}+F \supset \frac{F}{F_{m}} \leq \varphi .
$$

The rate of expenditure of product supplies for human accumulated during the previous phase, from wheat phytotron $U_{21}$ :

$$
\frac{d U_{21}}{d t}=\frac{-U_{21}\left(t_{i 1}\right)}{t_{\max 1}},
$$

The rate of «dead end» formation $B_{l}$ (organic matter falling out of the matter cycle by virtue of its incomplete closure) for wheat phytotron is calculated as:

$$
\begin{aligned}
& \frac{d B_{1}}{d t}=\left(\frac{1}{Y_{R 1 Z}}-1\right) \mu_{R 11} R_{11}+\left(\frac{1}{Y_{G Z}}-1\right)\left(1-\delta_{G Z}\right) \mu_{G Z 1} G_{1}+ \\
& +\left(\frac{1}{Y_{G R 1}}-1\right)\left(1-\delta_{G R 1}\right) \mu_{G R 11} G_{1}+\left(\frac{1}{Y_{R 2 C}}-1\right) \mu_{R 21} R_{21}
\end{aligned}
$$

\subsection{3. 'Radish phytotron' model}

The model for radish phytotron is similar to the model of wheat phytotron. Thus, here we will point to considerable distinctions only, without giving the full description.

The rate of radish growth $X_{2}$ is defined as:

$$
\frac{d X_{2}}{d t}=\mu_{X 2} J_{2},
$$


where $J_{2}$ is the surface area of radish growth chamber, $\mu_{X 2}$ is radish specific growth rate,

$$
\mu_{X 2}=k_{2} L_{\mathrm{CO}_{2}} L_{E X 2} L_{S 2} c_{2} a_{2}\left(1-e^{\left.-b_{2} t_{2}\right)}\right)^{6},
$$

where $k_{2}$ is the coefficient of radish growth rate dependence on the photosynthesis, $L_{E X 2}$ is the coefficient of radish growth limitation by illumination, $L_{S 2}$ is the coefficient of radish limitation by the content of bioganic elements in the growth chamber, $a_{2}, b_{2}, c_{2}$ are experimental constants.

$$
L_{E X 1}=-0.00001 \cdot E^{2}+0,0084 \cdot E+0,0169 .
$$

The dependence (29) was obtained by approximation of experimental data (Tikhomirov et al., 2003a).

$$
L_{S 2}=\min \left\{K_{S_{1} 2} S_{1}, K_{S_{2} 2} S_{2}, K_{S_{3} 2} S_{3}, 1\right\},
$$

where $K_{S_{1} 2}, K_{S_{2} 2}, K_{S_{3} 2}$ are the constants of radish growth limitation by the content of mineral nitrogen, phosphorus and iron in growth chamber respectively, $t_{2}$ is the current period for radish.

The following description goes by the analogy with wheat model.

\subsection{Modelling of the processes}

\section{associated with planting}

for the next cycle

Since not all processes in this model are continuous, the differential equations are not sufficient for their description. For each growth chamber there is a moment of growth cycle completion, when harvesting and planting for the next cycle as well as biomass exchange between wheat phytotron and mycotron (straw goes to fungi) take place.

Thus, at the given time period $\left(\mathrm{t}=\mathrm{t}_{\max 1}\right.$ for wheat phytotron and mycotron; $\mathrm{t}=\mathrm{t}_{\max 2}$ for radish phytotron) the following ratios are implemented (here [ ]* is the value after mass redistribution; [] - before redistribution): a) For wheat phytotron and mycotron:

$$
F_{m}{ }^{*}=F_{m I N I T},
$$

where $F_{m I N I T}$ is initial mass of mycelium,

$$
\begin{aligned}
& F^{*}=0, \\
& H^{*}=X-l_{11} X_{1}-l_{2} X_{1},
\end{aligned}
$$

where $l_{l l}$ is the quantity of roots in wheat total mass, $l_{2}$ is the quantity of grains in wheat total mass,

$$
X_{1}^{*}=X_{I N I T 1},
$$

where $X_{I N I T 1}$ is the mass of planted grains,

$$
\begin{aligned}
& Z_{1}^{*}=Z_{1}+l_{11} X_{1}+\left(F_{m}-F_{m I N I T}\right)+F+H, \\
& U_{21}{ }^{*}=U_{21}+U_{11}+\left(l_{2} X_{1}-X_{I N I T 1}\right) .
\end{aligned}
$$

\section{б) For radish phytotron:}

$$
X_{2}^{*}=X_{\text {INIT2 }},
$$

where $X_{I N I T 2}$ is the mass of planted radish seeds,

$$
Z_{1}^{*}=Z_{1}+\left(1-l_{12}\right) X_{2},
$$

where $l_{12}$ is the quantity of edible roots in radish total mass,

$$
U_{22} *=U_{22}+\left(l_{12} X_{2}-X_{\text {INIT2 }}\right) .
$$

Other variables of the system do not change during mass redistribution.

\subsection{The calculation of conveyor organization of the system}

Since the 'phytocenosis - soil-like substrategas exchange with a human' closed system has a conveyor of growth chambers of different ages in each compartment, a similar conveyor is organized in the model system, where each element has its own current model period. Each element of the conveyor is calculated separately, the total biomass of each element is summed up conveyor-wise. 
The total mass of mushroom mycelium in the system $F_{m \text { tot }}$ can be written as:

$$
F_{m \text { tot }}=\sum_{n=1}^{q} F_{m n},
$$

where $q$ is the number of conveyor age groups for wheat phytotron and mycotron.

Подобным же образом записываем the total mass of mushroom fruit bodies in the system $F_{\text {tot }}$, the total straw mass in the system $H_{\text {tot }}$, the total mass of wheat in the system $X_{1 \text { tot }}$, the total mass of radish in the system $X_{2}$ tot .

The total mass of the «dead end» in the system $B_{t o t}$ can be written as:

$$
B_{\text {tot }}=\sum_{n=1}^{q}\left(B_{F}+B_{1}\right)_{n}+\sum_{l=1}^{p} B_{2} l,
$$

where $p$ is the number of conveyor age groups for radish phytotron.

The total mass of worms in the system $G_{t o t}$ :

$$
G_{t o t}=\sum_{n=1}^{q} G_{1 n}+\sum_{l=1}^{p} G_{2} l
$$

Similarly we write down the total mass of bacteria-1 in the system $R_{1 \text { tot }}$, the total mass of dead organic matter in the system $Z_{t o t}$, the total mass of bacteria-2 in the system $R_{2}$ tot , the total mass of worms' coprolites in the system $C_{\text {tot }}$, the total mass of mineral nitrogen in the system $S_{1}$ ${ }_{t o t}$, the total mass of mineral phosphorus in the system $S_{2 \text { tot }}$, the total mass of mineral iron in the system $S_{3 \text { tot }}$.

The total mass of products intended for humans in the system $U_{\text {tot }}$ :

$$
U_{t o t}=\sum_{n=1}^{q}\left(U_{11 n}+U_{21 n}\right)+\sum_{l=1}^{p} U_{22 l},
$$

\subsection{Equations for oxygen and carbon dioxide of the module atmosphere}

Another important component of a closed ecological system are atmospheric constituents - oxygen and carbon dioxide. Their dynamics can be calculated according to differential equations, as in the works of Abrosov et al., 1981.
The change of oxygen mass in the system $Q$ is defined as:

$$
\begin{aligned}
& \frac{d Q}{d t}=\sum_{n=1}^{q}\left(L _ { O _ { 2 } } \left(-a_{F m}\left(\mu_{m n}+\gamma_{m}\right) F_{m n}-\right.\right. \\
& -a_{G}\left(\mu_{G 1 n}+\gamma_{G}\right) G_{1 n}-a_{R 1}\left(\mu_{R 11 n}+\gamma_{R 1}\right) R_{11 n}- \\
& \left.-a_{R 2}\left(\mu_{R 21 n}+\gamma_{R 2}\right) R_{21 n}-a_{U}\left(\frac{-U_{21 n}\left(t_{i 1 n}\right)}{t_{\max 1}}\right)\right)+ \\
& \left.+\frac{J_{1} k_{1} L_{C O_{2}} L_{E X 1} L_{S 1} c_{1}\left(a_{1}\left(t_{1 n}-t_{11 n}\right)-b_{1}\left(t_{1 n}-t_{11 n}\right)^{3 / 2}\right)}{B Y_{X W}}\right)+ \\
& +\sum_{l=1}^{p}\left(L _ { O _ { 2 } } \left(-a_{G}\left(\mu_{G 2 l}+\gamma_{G}\right) G_{2 l}-a_{R 1}\left(\mu_{R 12 l}+\gamma_{R 1}\right) R_{12 l}-\right.\right. \\
& \left.-a_{R 2}\left(\mu_{R 22 l}+\gamma_{R 2}\right) R_{22 l}-a_{U} \frac{U_{22 l}\left(t_{i 2 l}\right)}{t_{\max 2}}\right)+ \\
& \left.+\frac{J_{2} k_{2} L_{C O_{2}} L_{E X 2} L_{S 2} c_{2} a_{2}\left(1-e^{-b_{2} t_{2} l}\right)^{6}}{B Y_{X W}}\right),
\end{aligned}
$$

where $a_{F m}, a_{G}, a_{R 1}, a_{R 2}, a_{U}$ are the coefficients showing the amount of oxygen used per unit of biomass consumed during respiration by mushrooms mycelium, worms, bacteria-1, bacteria-2 and virtual human respectively, $B$ is the assimilation (photosynthetic) coefficient of producers, $Y_{X W}$ - coefficient of producer yield with respect to carbon dioxide.

The change of carbon dioxide mass in the system $W$ is defined in a similar way:

$\frac{d W}{d t}=\sum_{n=1}^{q}\left(L_{O_{2}}\left(a_{F m} D_{F m}\left(\mu_{m n}+\gamma_{m}\right) F_{m n}+\right.\right.$

$+a_{G} D_{G}\left(\mu_{G 1 n}+\gamma_{G}\right) G_{1 n}+a_{R 1} D_{R 1}\left(\mu_{R 11 n}+\gamma_{R 1}\right) R_{11 n}+$

$\left.+a_{R 2} D_{R 2}\left(\mu_{R 21 n}+\gamma_{R 2}\right) R_{21 n}+a_{U} D_{U} \frac{U_{21 n}\left(t_{i n n}\right)}{t_{\max 1}}\right)-$

$\left.-J_{1} k_{1} L_{C O_{2}} L_{E X 1} L_{S 1} C_{1}\left(a_{1}\left(t_{1 n}-t_{11 n}\right)-b_{1}\left(t_{1 n}-t_{11 n}\right)^{3 / 2}\right) / Y_{X W}\right)+$

$\sum_{l=1}^{p}\left(L_{O_{2}}\left(a_{G} D_{G}\left(\mu_{G 2 l}+\gamma_{G}\right) G_{2 l}+a_{R 1} D_{R 1}\left(\mu_{R 12 l}+\gamma_{R 1}\right) R_{12 l}+\right.\right.$

$\left.+a_{R 2} D_{R 2}\left(\mu_{R 22 l}+\gamma_{R 2}\right) R_{22 l}+a_{U} D_{U} \frac{U_{22 l}\left(t_{i 2 l}\right)}{t_{\max 2}}\right)-$

$\left.-J_{2} k_{2} L_{C O_{2}} L_{E X 2} L_{S 2} c_{2} a_{2}\left(1-e^{\left.-b_{2} t_{2 l}\right)}\right)^{6} / Y_{X W}\right)$,

where $D_{F m}, D_{G}, D_{R 1}, D_{R 2}, D_{U}$ are the coefficients of respiration for mushrooms mycelium, worms, bacteria-1, bacteria-2 and a virtual human.

\section{The degree of closedness}

\section{of biotic matter turnover}

The important characteristics of matter biotic turnover, determining the sustainability 
and resistance of super-organism systems with bioturnover, are its intensity and the degree of closedness. We should note that the latter feature is favourable for maintaining the integral properties of the biotic system. We introduce the measure of biotic closedness of matter turnover for similar systems, including ecological.

The degree of closedness of the biotic turnover was determined in a way similar to the approach proposed in Finn's works $(1976,1978)$ for the determination of the cycling index (using a similar, though essentially different, approach proposed by (Gubanov, Degermendzhy, 2003, 2008; Tikhomirov et al., 2003a)). Namely, the degree of closedness of the biotic turnover $(=$ coefficient of the closedness of turnover) is the ratio of the flow rate of the substance supplied by heterotrophic organisms to producers (autotrophic organisms) $(\dot{\Omega})$ to the sum of the flow rates of the substance supplied by heterotrophs to autotrophs $(\dot{\Omega})$ and the substance going to the dead end $(\dot{B})$, i.e. the substance (or deposition), which cannot be completely oxidized (reduced) to initial mineral (biogenic) elements used by autotrophs in biosynthesis, by biota forming the system, and thus, naturally falling out of the biotic turnover.
a) $C l_{i}=\frac{\sum_{k} \dot{\Omega}_{i k}}{\sum_{k} \dot{\Omega}_{i k}+\sum_{l} \dot{B}_{i l}}$,
b) $C l=\frac{\sum_{i} \sum_{k} \dot{\Omega}_{i k}}{\sum_{i} \sum_{k} \dot{\Omega}_{i k}+\sum_{i} \sum_{l} \dot{B}_{i l}}$.

where $\mathrm{Cl}_{i}, \mathrm{Cl}$ are coefficients of the closedness of turnover for the $i$-th biogenic element and the matter as a whole, $k$ and $l$ are all possible channels through which the substances move from heterotrophic organisms to producers and to the dead end. Evidently, $0 \leq C l_{i}, C l \leq 1$.

This determination of the degree of closedness is realistic, at least for the systems that must contain some material stores, e.g. systems of the LSS type, including the systems discussed here.

A priori, we can assert that the degree of closedness on various elements is different. From this assertion and determination of the turnover degree of closedness (46) it follows that

$$
\breve{C l} l_{j}<C l<\hat{C} l_{k},
$$

where $\breve{C} l_{j}, \hat{C} l_{k}$ are the minimum and the maximum closedness on some $j$ and $k$ elements. To all appearances, (47) is a general property.

From the formulas (46), we can see that the change of $\mathrm{Cl}$ goes in the same direction with change of $C l_{i}$ for any $i^{\text {th }}$ chemical element. But it is obvious that $\mathrm{Cl}$ change happens not necessarily unidirectional with $C l_{i}$ change for any $i^{\text {th }}$ chemical element. It is obvious that, if, on any account, the degree of closedness of matter biotic turnover as the whole $(\mathrm{Cl})$ stays invariable at the change of degree of closedness on some $i$-th element $\left(\mathrm{Cl}_{i}\right)$, then there should be the change of degree of closedness at least on one element $m$ with the coefficient opposite to $i$ element. So, the change of degree of closedness of biotic turnover on some element with the same coefficient of closedness on the matter as the whole, results in the change of closedness degree of the turnover with opposite coefficient on the other element (or elements).

In practice it means the following. For example, if there is a need to increase the BLSS degree of closedness on some element (usually, there is an attempt to reach the high degree of closedness on the key elements - C, O, S, N etc) and to maintain the degree of closedness as the whole (for mass optimum, energy supply, or other requirements), it is obvious, that the spontaneous decrease of closedness on the other element (or elements) will, most probably, take place, which is not always beneficial, as this may even drop out of sight of the researcher, since it is technically difficult to track and correct the closedness on all elements simultaneously. 
Thus, the mathematical model (1-45) of the BLSS experimental module «phytocenosis soil-like substrate - gas exchange with a human» based on higher plants (wheat and radish) and use of soil-like substrate (SLS) intended for $1 / 30$ of a virtually present human has been constructed. The new method of measuring the degree of closedness of matter biotic turnover in superorganism systems (46) has been proposed. The verification of the model and various scenarios will be introduced in the next paper.

\section{Acknowledgments}

The work was supported by Grant INTASESA 099-044, by the Krasnoyarsk Regional Scientific Foundation and RFBR grant No. 0304-96121-П2003yenisey_a .

\section{References}

Abrosov N.S., Gubanov V.G., Kovrov V.G. (1981) Experiment-theoretical analysis of material cycling in a closed microecosystem. 1. Mathematical modeling // Proc. SB USSR AS (Biological Sciences) 15 (3): 65-68.

Abrosov N.S., Degermendzhy AG., Gubanov V.G. et al. (1992) Water quality forecast and estimate of ecological consequences of water consumption. In: Gitelson I.I. (ed.) Biophysics of cell populations and super-organism systems. Nauka, Novosibirsk, Russia, p. 71-92.

Gubanov V.G., Barkhatov Yu.V., Manukovsky N.S., Tikhomirov A.A., Degermendzhy A.G., Gros J.B., Lasseur Ch. (2007) Mathematical modeling of the biological life support system module. 1/2. Description of the model. Elektronnyi Zhurnal (The Electron Journal) «Issledovano v Rossii», 039e, 398-413, http://zhurnal.ape.relarn.ru/articles/2007/039e.pdf

Gubanov V.G., Degermendzhy A.G. (2003) About closure of biotic matter turnover in superorganism systems (methodological aspect). Degree of biotic closure. In: Volova T.G. (ed.) Outlines of ecological biophysics, Edition SB RAS, Novosibirsk, p. 318 - 333.

Gubanov V.G., Degermendzhy A.G. (2008) Biotic Turnover in Superorganism Systems: Several Principles of Establishment and Sustenance (Theoretical Analysis, Debatable Issues). In: Dobretsov N., Kolchanov N., Rozanov A., Zavarzin G. (eds.) Biosphere Origin and Evolution, Springer, New York, p. 327-348.

Finn J.T. (1976) Measures of ecosystem structure and function derived from analysis of flows, Journal of Theoretical Biology 56: $363-380$.

Finn J.T. (1978) Cycling index: a general definition for cycling in compartment models. In: Adriano and Brisbin I.L. (eds) Environmental Chemistry and Cycling Processes, DOE Symposium Series 45, CONF 760429, National Technical Service, Spring-field, Virginia, USA., p. 138 - 164.

Gitelson I.I., Kovrov B.G., Lisovsky G.M., Okladnikov Yu.N., Rerberg M.S., Sidko F.Ya., Terskov I.A. (1975) Experimental ecological systems with humans. In: V.N. Chernigovsky (ed.) Problemy Kosmicheskoi Biologii (Problems of Space Biology) 28, Nauka, Moscow, Russia, p. 261 - 284.

Gitelson I.I, Lisovsky G.M., Tikhomirov A.A. (1997) Optimal structure of plant conveyor for human life support in a closed ecosystem «BIOS-3». In: E. Goto et al. (eds.) Plant Production in Closed Ecosystems, Kluver Academic Publishers, Printed in the Netherlands, p.297-304.

Gubanov V.G., Degermendzhy A.G. (2002) Biophysical investigations of aquatic ecosystems In: Gitelson I.I and Pechurkin N.S. (eds.) Ecological Biophysics. 2. Biophysics of ground and aquatic ecosystems. Logos, Moscow, Russia, p. 247-359. 
Kudenko Yu.A., Gribovskaya I.V., Pavlenko R.A. (1997) Mineralization of wastes of human vital activity and plants to be used in a life support system. Acta Astronautica 41(3): 193 - 196.

Manukovsky N.S., Kovalev V.S., Zolotukhin I.G., Rygalov V.Ye. (1996) Biotransformation of plant biomass in closed cycle, 26th International Conference on Environmental Systems, Monterey, California USA SAE Technnical paper series № 961417, 5p.

Manukovsky N.S., Kovalev V.S., Rygalov V.Ye., Zolotukhin I.G. (1997) Waste bioregeneration in life support CES: development of soil organic substrate. Adv. Space Res. 20(10): 1827-1832.

Tikhomirov A.A., Ushakova S.A.., Manukovsky N.S., Lisovsky G.M., Kudenko Yu.A., Kovalev V.S., Gubanov V.G., Barkhatov Yu.V., Gribovskaya I.V., Zolotukhin I.G., Gros J.B., Lasseur Ch. (2003a) Mass exchange in an experimental new-generation LSS model based on biological regeneration of environment. Adv. Space Res. 31(7): 1711-1720.

Tikhomirov A.A., Ushakova S.A.., Manukovsky N.S., Lisovsky G.M., Kudenko Yu.A., Kovalev V.S., Gribovskaya I.V., Tirranen L.S., Zolotukhin I.G., Gros J.B., Lasseur Ch. (2003b) Synthesis of biomass and utilization of plants wastes in a physical model of biological Life-Support System. Act.Astr. 53: 249-257.

Zamknutaya sistema: «chelovek - vysshiye rasteniya» (Closed system: «human - higher plants») (1979). Nauka: Novosibirsk, Russia. 160 p.

\section{Математическое моделирование}

\section{и вычислительная имитация модуля}

\section{биологической системы жизнеобеспечения}

\section{1/2. Описание модели}

\section{В.Г. Губанов $^{\text {a }}$, Ю.В. Бархатов ${ }^{\text {a*}}$, Н.С. Мануковский ${ }^{a}$, А.А. Тихомиров ${ }^{\mathrm{a}, \boldsymbol{\sigma}}$, А.Г. Дегерменджи ${ }^{\mathrm{a}, \boldsymbol{\sigma}}$, Жан-Бернар Р. Гро ${ }^{\text {, К. Лассёр }}$ \\ a Институт биофизики СО РАН, \\ Россия 660036, Красноярск, Академгородок \\ ${ }^{\sigma}$ Сибирский федеральный университет, Россия 660041, Красноярск, пр. Свободный, 79 в ЛГСБ, Университет Блеза Паскаля, Франциия 63174, Клермонт-Ферран, ВР206 \\ ¿ Европейское космическое агентство,} отдел жизнеобеспечения и контроля окружающей среды, Нидерланды 2200 AG, Нордвейк, Postbus 299

Для оиенки характера функиионирования экспериментального модуля биологической системь жизнеобеспечения и возможности управления им построена математическая модель, опирающаясяна кинетическиекоэффищиенты изависимости, полученные в экспериментальных исследованиях.

Математическая модель состоит из двух компартментов - моделей «фитотрона» (с пшеницей и с редисом) и модели «микотрона» (для грибов). В модель включень следующие 
компоненты: пшеница, редис, солома (перерабатываемая мицелием), мертвое органическое вещество в фитотроне, съедобные грибы (плодовые тела и мицелий), черви, продукты жизнедеятельности червей (копролиты), вермикомпост, использующийся как почвоподобный субстрат, бактериальная микрофлора, минеральные формы биогенных элементов (азот, фосфор, железо), продукция системы для человека (зерно пшеницы, корнеплоды редиса, плодовые тела грибов), кислород и углекислый газ. При постоянном газообмене массообмен между компартментами происходит только во время снятия урожая. Учитывается конвейерный характер функиионирования замкнутой экосистемы - число возрастов культуры может регулироваться (в эксперименте - четыре и восемь возрастов). Также поддается регулированию длина конвейерного иикла. По пище и газообмену модуль рассчитан на условное присутствие 1/30 доли человека.

Модель позволяет оценить значения всех учитываемых динамических компонентов системы приразличныхусловиях ирежимахее функиионирования, в частности, притруднореализуемых в эксперименте условиях. Формализован коэффиииент замкнутости биотического круговорота вещества для систем на запасах вещества.

Ключевые слова: математическое моделирование, биологическая система жизнеобеспечения, коэффициент замкнутости 